\title{
Study on the selenium accumulation of peach seedlings
}

\author{
Caifang Wu ${ }^{1}$, Yiping Dong ${ }^{2}$ Xu Chen², Yuhui Bie² , Yuefeng $\mathrm{Hou}^{2}$ and Lijin $\mathrm{Lin}^{1 *}$ \\ ${ }^{1}$ Institute of Pomology and Olericulture, Sichuan Agricultural University, Chengdu, Sichuan, 611130, China \\ ${ }^{2}$ College of Horticulture, Sichuan Agricultural University, Chengdu, Sichuan, 611130, China
}

\begin{abstract}
An experiment was conducted to study the effect of peach seedlings (Prunus davidiana) grown in nutrient solution with different selenium concentration. The results showed that selenium concentration were 0.05 and $0.10 \mathrm{mg} / \mathrm{L}$ which caused a marked increase of roots and shoorts biomass, and the root/shoot ratio were relatively low ( 0.180 and 0.170$)$ compared with control, and other selenium treatments decreased significantly the biomass. Consequently, 0.05 and $0.10 \mathrm{mg} / \mathrm{L}$ selenium treatments were conducive to peach seedlings growth, while the peach seedlings was inhibited significantly by the increasing concentration of selenium $(\geq 0.10 \mathrm{mg} / \mathrm{L})$. Selenium content of peach seedlings increased remarkably with the increase of selenium concentration that indicated the accumulation of selenium in peach seedlings had a linear relation with the dose of selenium. Above all, when selenium concentration in the range of 0-0.10 mg/ L, which not only promotes peach seedlings growth, but also increases peach seedlings selenium content.
\end{abstract}

\section{Introduction}

Selenium is an essential micronutrient and also toxic for many organisms, including plants, animals and humans, with a very narrow window between deficiency and toxicity [1-2]. Selenium deficiency and high concentration selenium inhibit plant growth, and low concentration selenium can promote plant growth [3-4]. Lee et al. found that the growth of pakchoi was promoted at lower selenite concentration (selenium $\leq 1.0 \mathrm{mg} / \mathrm{L}$ ), while it was inhibited at higher selenite concentration (selenium $\geq 2.5 \mathrm{mg} / \mathrm{L}$ ). In general, in selenite-treated plants, most of the selenite stays in the roots [5], and inhibition of roots growth was higher sensitive. Hui $\mathrm{M}$ et al. shows that the inhibition effects on root growth were found when selenium concentration was higher than 2 $\mathrm{mg} / \mathrm{L}$ selenium for broccoli, medic and parsley, and higher than $4 \mathrm{mg} / \mathrm{L}$ selenium for wheat, barley and radish [6].

The response of different plants to selenium was also different, and the effects of selenium on fruit growth of peach and the model of selenium accumulation in fruits had been reported, which showed that the ability of selenium absorption in peach was poor [7]. In this study, hydroponic experiment was conducted to study the effect of peach seedlings (Prunus davidiana) grown in nutrient solution with different selenium concentrations and to choose the suitable concentration for peach.

\section{$2 \quad$ Materials and methods}

\section{$2.1 \quad$ Materials}

The seeds of peach were purchased from a market in Chengdu, Sichuan, China.

\subsection{Experimental design}

The experiments were conducted with Hoagland solution under greenhouse conditions at the Chengdu campus of Sichuan Agricultural University from February to April 2019. After breaking dormancy, the plump seeds were surface-sterilized and sown, and then these seedlings were transferred to plastic nutrition bowls containing quartz sand. Subsequently, selecting the seedlings germinated robustly in good trim (about $10 \mathrm{~cm}$ high), replenished a ration of water and nutrient solution to seedlings on a regular basis. The selenite $\left(\mathrm{Na}_{2} \mathrm{SeO}_{3}\right)$ concentration in the nutrient solution was set as follows: $0,0.05,0.10,0.25,0.50,1.0$ and $2.0 \mathrm{mg} / \mathrm{L}$, the nutrient solution without selenium was used as the control group. The seedings were experienced the treatments for one month, the roots, stem, and leaves of each plant were separately harvested, blanched at $110{ }^{\circ} \mathrm{C}$ for $15 \mathrm{~min}$, dried at $75{ }^{\circ} \mathrm{C}$ until reaching a constant weight, and weighed. The total selenium concentration was determined by Hydride Generation Atomic Fluorescence Spectrometry (HG-AFS 9230) [8].

\subsection{Statistical analysis}

Use Microsoft Excel 2010 and DPS 7.5 software for statistical analysis, data analysis by one-way ANOVA with least significant difference at $5 \%$ confidence level. Translocation factor $=$ the selenium content of shoot $/$ root selenium content [9].

\footnotetext{
*Corresponding author's e-mail: 11j800924@qq.com
} 


\section{$3 \quad$ Results and discussion}

\subsection{Biomass of peach seedlings}

Different concentration of selenium had significant effects on the growth of peach seedlings (Table 1). Selenium treatments caused a marked decrease of roots biomass compared with control, expect for selenium concentration was 0.05 and $0.10 \mathrm{mg} / \mathrm{L}$, furthermore, the roots biomass was markedly higher than that of other treatments when selenium concentration was $0.05 \mathrm{mg} / \mathrm{L}$. Compared with the control, $0.05 \mathrm{mg} / \mathrm{L}$ selenium treatment had no significant effect on the stems biomass, and other selenium treatments decreased significantly the stems biomass. The leaves biomass had the same varying trends with the shoots biomass, 0.05 and $0.10 \mathrm{mg} / \mathrm{L}$ selenium treatments caused significant increases of leaves biomass increases by $71.75 \%$ and $37.27 \%$ respectively, and significantly increased shoots biomass by $39.79 \%$ and $18.24 \%$ respectively, compared with the control. Moreover, the root/shoot ratio were relatively low $(0.180$ and 0.170$)$ when selenium concentration was 0.05 and $0.10 \mathrm{mg} / \mathrm{L}$.

Table 1. Biomass of peach seedlings.

\begin{tabular}{cccccc}
\hline $\begin{array}{c}\text { Selenium } \\
\text { concentration }\end{array}$ & $\begin{array}{c}\text { Roots } \\
\text { (g/plant) }\end{array}$ & $\begin{array}{c}\text { Stems } \\
\text { (g/plant) }\end{array}$ & $\begin{array}{c}\text { Leaves } \\
\text { (g/plant })\end{array}$ & $\begin{array}{c}\text { Shoots } \\
\text { (g/plant) }\end{array}$ & $\begin{array}{c}\text { Root/shoot } \\
\text { ratio }\end{array}$ \\
\hline 0 & $0.275 \pm 0.008 \mathrm{~b}$ & $0.573 \pm 0.018 \mathrm{a}$ & $0.754 \pm 0.016 \mathrm{c}$ & $1.327 \pm 0.034 \mathrm{c}$ & 0.207 \\
0.05 & $0.333 \pm 0.012 \mathrm{a}$ & $0.561 \pm 0.020 \mathrm{a}$ & $1.295 \pm 0.025 \mathrm{a}$ & $1.855 \pm 0.005 \mathrm{a}$ & 0.180 \\
0.10 & $0.267 \pm 0.006 \mathrm{bc}$ & $0.534 \pm 0.014 \mathrm{~b}$ & $1.035 \pm 0.042 \mathrm{~b}$ & $1.569 \pm 0.028 \mathrm{~b}$ & 0.170 \\
0.25 & $0.254 \pm 0.011 \mathrm{~cd}$ & $0.385 \pm 0.010 \mathrm{c}$ & $0.596 \pm 0.020 \mathrm{~d}$ & $0.982 \pm 0.011 \mathrm{~d}$ & 0.259 \\
0.50 & $0.243 \pm 0.007 \mathrm{de}$ & $0.283 \pm 0.012 \mathrm{~d}$ & $0.488 \pm 0.007 \mathrm{e}$ & $0.771 \pm 0.019 \mathrm{e}$ & 0.315 \\
1.00 & $0.229 \pm 0.008 \mathrm{e}$ & $0.260 \pm 0.011 \mathrm{de}$ & $0.461 \pm 0.014 \mathrm{e}$ & $0.721 \pm 0.025 \mathrm{f}$ & 0.317 \\
2.00 & $0.214 \pm 0.005 \mathrm{f}$ & $0.252 \pm 0.019 \mathrm{e}$ & $0.301 \pm 0.010 \mathrm{f}$ & $0.553 \pm 0.029 \mathrm{~g}$ & 0.387 \\
\hline
\end{tabular}

Values are mean \pm SD $(n=3)$. Different letters indicated significant differences among treatments at 0.05 levels. The below tables were the same.

\subsection{Selenium content in peach seedlings}

Total selenium content was examined in roots, stems and leaves of peach seedlings (Table 2). With the increase of selenium concentration, the selenium content in roots, stems, leaves and shoots of peach seedlings increased remarkably. The selenium content increased to $1.3-290.2$ times in roots and 0.7-13.9 times in shoots of peach seedlings, respectively. And selenium content in roots was significantly higher than that in shoots (included stems and leaves). Translocation factor was lower than that of the control.

Table 2. Selenium content in peach seedlings.

\begin{tabular}{cccccc}
\hline $\begin{array}{c}\text { Selenium } \\
\text { concentration }\end{array}$ & $\begin{array}{c}\text { Roots } \\
(\mathrm{mg} / \mathrm{kg})\end{array}$ & $\begin{array}{c}\text { Stems } \\
(\mathrm{mg} / \mathrm{kg})\end{array}$ & $\begin{array}{c}\text { Leaves } \\
(\mathrm{mg} / \mathrm{kg})\end{array}$ & $\begin{array}{c}\text { Shoots } \\
(\mathrm{mg} / \mathrm{kg})\end{array}$ & $\begin{array}{c}\text { Translocation } \\
\text { factor }\end{array}$ \\
\hline 0 & $0.523 \pm 0.005 \mathrm{f}$ & $0.376 \pm 0.008 \mathrm{~g}$ & $0.647 \pm 0.009 \mathrm{f}$ & $0.530 \pm 0.008 \mathrm{~g}$ & 1.013 \\
0.05 & $1.178 \pm 0.012 \mathrm{f}$ & $0.957 \pm 0.033 \mathrm{f}$ & $0.877 \pm 0.021 \mathrm{f}$ & $0.901 \pm 0.023 \mathrm{f}$ & 0.765 \\
0.10 & $38.30 \pm 0.746 \mathrm{e}$ & $1.533 \pm 0.044 \mathrm{e}$ & $2.070 \pm 0.083 \mathrm{e}$ & $1.886 \pm 0.032 \mathrm{e}$ & 0.049 \\
0.25 & $69.52 \pm 2.270 \mathrm{~d}$ & $3.522 \pm 0.066 \mathrm{~d}$ & $3.844 \pm 0.118 \mathrm{~d}$ & $3.718 \pm 0.102 \mathrm{~d}$ & 0.053 \\
0.50 & $105.2 \pm 4.900 \mathrm{c}$ & $5.652 \pm 0.158 \mathrm{c}$ & $5.975 \pm 0.170 \mathrm{c}$ & $5.856 \pm 0.168 \mathrm{c}$ & 0.056 \\
1.00 & $135.5 \pm 4.201 \mathrm{~b}$ & $6.878 \pm 0.257 \mathrm{~b}$ & $7.036 \pm 0.219 \mathrm{~b}$ & $6.978 \pm 0.047 \mathrm{~b}$ & 0.052 \\
2.00 & $152.3 \pm 1.740 \mathrm{a}$ & $7.258 \pm 0.247 \mathrm{a}$ & $8.456 \pm 0.245 \mathrm{a}$ & $7.911 \pm 0.259 \mathrm{a}$ & 0.052 \\
\hline
\end{tabular}

\section{Conclusions}

The plant growth was promoted at lower selenium concentration, and inhibited at higher selenium concentration [10]. Similar results were observed in this experiment, 0.05 and $0.10 \mathrm{mg} / \mathrm{L}$ selenium treatments caused significant increases of the biomass and led to a relatively low root/shoot ratio $(0.180$ and 0.170$)$, which were conducive to peach seedlings growth, especially the growth of shoot. While the peach seedlings was inhibited significantly by the increasing concentration of selenium $(\geq 0.10 \mathrm{mg} / \mathrm{L})$, mainly embodied in the biomass decreased rapidly. The accumulation of selenium in plant has a linear relation with the dose of selenium [11]. The selenium content of peach seedlings increased remarkably with the increase of selenium concentration.

Above all, when selenium concentration in the range of $0-0.10 \mathrm{mg} / \mathrm{L}$, which not only promotes peach seedlings growth, but also increases peach seedlings selenium content. 


\section{Acknowledgments}

This work was financially supported by the Application Infrastructure Project of Science and Technology Department of Sichuan Province (2016JY0258).

\section{References}

1. Zhu, Y.G., Pilon-Smits, E.A.H., Zhao, F.J., Williams, P.N., Meharg, A.A. (2009) Selenium in higher plants: understanding mechanisms for biofortification and phytoremediation. Trends Plant Sci., 14: 436-442.

2. Schiavon, M., Pilon-Smits, E.A. (2017) The fascinating facets of plant selenium accumulation -biochemistry, physiology, evolution and ecology. New Phytol., 213: 1582-1596.

3. Xu, W. (2009) Bio-availability of Selenium and Its Absorption for Plants. Anhui Agric. Sci. Bull., 15:46-47.

4. Schnug, E., El-Ramady, H., Abdalla, N., Taha, H., Alshaal, T., El-Henawy, A., Faizy, S., Shams, M., Youssef, S., Shalaby, T., Bayoumi, Y., Elhawat, N., Shehata, S., Sztrik, A., Prokisch, J.Z., Fa'ri, M., Domokos-szabolcsy, E., Pilon-Smits, E., Selmar, D., Haneklaus, S. (2016) Selenium and nano-selenium in plant nutrition. Environ. Chem. Lett., 14: 123-147.

5. Li, H.F., Mcgrath, S.P., Zhao, F.J. (2008) Selenium uptake, translocation and speciation in wheat supplied with selenate or selenite. New Phytol., 178: 92-102.

6. Mao. H.,Wang, Z.H., Lyons, G., Mcdonald, G. (2011) Effects of selenium valence states and concentration on germination and root growth of six crop species. J. Agro-Environ. Sci., 30: 19581965.

7. Zhang,H.Y., Han, T., Tian, L., Wang, Y.N., Jia, H.J. (2010) Accumulation of $\mathrm{Se}$ in peach, jujube and strawberry after spraying Sefertilizer on leaves. J. Fruit Sci., 62: 547-566.

8. Yuan, L., Zhu, Y., Lin, Z.Q., Banuelos, G., Li, W., Yin, X. (2013) A novel selenocystineaccumulating plant in selenium-mine drainage area in enshi, china. PLoS ONE, 8: e65615.

9. Hawrylak-Nowak, B. (2013) Comparative effects of selenite and selenate on growth and selenium accumulation in lettuce plants under hydroponic conditions. Plant Growth Regul., 70: 149-157.

10. Li, D.C., Zhu, Z.J., Xu, Z.H., Qian, Q.Q. (2003) Effects of selenium on the growth and nutrient absorption of pakchoi. Plant Nut. Fert. Sci., 9:353-358.

11. Schiavon, M., Moro, I., Pilon-Smits, E., Matozzo, V., Malagoli, M., Vecchia, F. (2012) Accumulation of selenium in Ulva sp and effects on morphology, ultrastructure and antioxidant enzymes and metabolites. Aquat. Toxicol., 122123: $222-231$. 